\title{
The nitrate concentration of domestic vegetables on Helsinki market in summer and autumn 1984
}

\author{
SEIJA AHONEN and IRIS KUOKKANEN
}

Helsinki University

Dept. for Horticulture

SF-00710 Helsinki

PIRJO-LIISA PENTTILÄ

Nat. Board of Trade and

Consumer Interest, $P B 9$

SF-00531 Helsinki

\begin{abstract}
Nitrate concentration of some domestic vegetables at Helsinki district market was studied during the summer and autumn months of the year 1984. The species were cabbage (Brassica oleracea var capitata), chinese cabbage (Brassica pekinensis), kohlrabi (Brassica oleracea var gongylodes), turnip (Brassica rapa), carrot (Daucus carota subsp. sativus) and crisphead and butter head lettuce (Lactuca sativa var. capitata). The 395 samples were analysed with an ion specific electrode.

There was a wide range of nitrate concentrations within each species. The mean concentrations mg nitrates $/ \mathrm{kg}$ of fresh weight were the following: butter head lettuce 1835 , chinese cabbage 1057, kohlrabi 1008, crisphead lettuce 964, turnip 908, cabbage 607 and carrot 264 . The nitrate concentration of butter head lettuce in the autumn was more than twice as high as that in the summer, and vice versa as to cabbage samples. The nitrate concentration of carrot samples in the summer was about $40 \%$ higher than in the autumn.
\end{abstract}

Index words: butter head lettuce, cabbage, carrot, chinese cabbage, crisphead lettuce, kohlrabi, nitrate, turnip

\section{Introduction}

Nitrate and nitrite in human food might have some negative influences on health. Ac-

This investigation was committed at Helsinki University, Department for Horticulture, on the initial of $\mathrm{Na}$ tional Board of Trade and Consumer Interest, its Department of Consumer Affairs. The responsible person at the cording to Codex Alimentarius-commission the acceptable daily intake or ADI-value for potassium and sodium nitrate is $0-5 \mathrm{mg}$ and

Board was Pirjo-Liisa Penttilă. Vegetable samples were provided by this board, the study was planned and lead at Helsinki University by Seija Ahonen, and the samples analysed and data calculated by Iris Kuokkanen. 
that of corresponding nitrites $0-0,2 \mathrm{mg}$ per kilogram of body weight.

The major part of nitrates in human nutrition is of vegetable origin. Specially fresh vegetables can contain considerable amounts of nitrates. There are several factors affecting the $\mathrm{NO}_{3}$-concentration of vegetables: species, cultivar, part of the plant, source of the nutrient nitrogen, other nutrients, time of harvest and several environmental factors as light, temperature and humidity.

There has been few studies on the nitrate concentration of vegetables in Finland. In one earlier Finnish review (ANON 1983) it has been calculated, that potato is, because of its great consumption, the most important vegetabil source of nitrates. The $\mathrm{NO}_{3}$-concentration of potatoes on Finnish market was studied by means of the National Board of Trade and Consumer Interest in the year 1983 (MÄKÄRÄINEN 1984). As regards the major vegetable species, there hasn't recently been studies of this kind in our country. So the National Board of Trade and Consumer Interest commanced in the year 1984 a study on the nitrate concentration of domestic vegetables on Helsinki district fresh market.

\section{Material and methods}

The study aimed at determining the average nitrate contents of some vegetable species on Helsinki district fresh market and the possible variation in this contents due to time of harvest and method of growing (conventional vs. organic). All the samples were of domestic origin. The samples from conventionally grown products were taken mainly from the vegetable market of the food wholesale market centre of Helsinki city, preferably straight from growers. Samples were also taken from market places and retail stores. Samples from vegetables that were announced to be organically grown were taken at health food industry wholesale and retail stores.

Both leaf and root vegetables typical of freshmarket were taken into the investiga- tion. Species that are known to contain little nitrates, e.g. onion, were excluded, and so were those that are mainly rawmaterial for food industry, e.g. spinach and redbeet. Vegetable species chosen and numbers of samples gathered were the following: cabbage (89), chinese cabbage (60), kohlrabi (21), turnip (32), carrot (96), crisphead lettuce (43) and butter head lettuce (54), 395 samples in all. From them 78 samples were organically grown vegetables.

Nitrate concentrations were measured with the ion specific Orion Research electrode, the reference electrode being Double Junction Reference Electrode type 92-02. Sample size of different species varied from 3 to 15 pieces, the mean size being 5 pieces. Two parallel nitrate determinations were made from each sample.

The nitrate concentration of each sample was determined of fresh weight by extracting nitrate ions into $0,01 \mathrm{~N} \mathrm{KH}_{2} \mathrm{PO}_{4}$-solution: 50 grams' sample to 200 millilitres was homogenized for two minutes, and the nitrate concentration was measured immediately after filtering. It was calculated as $\mathrm{mg}$ nitrates in a kilogram of fresh weight (FW).

\section{Results}

\section{Range of nitrate concentrations}

The range of the nitrate concentrations of each vegetable species is presented in table 1 . Butter head lettuce had the highest mean concentration of nitrates, $1835 \mathrm{mg} / \mathrm{kg} \mathrm{FW}$, and carrot the lowest, $264 \mathrm{mg} / \mathrm{kg} \mathrm{FW}$. The widest range in concentrations was found in crisphead lettuce and cabbage, and the smallest in kohlrabi and chinese cabbage.

\section{Effect of sampling time on nitrate concentration}

In five of the seven species nitrate concentration was higher in the summer samples 
Table 1. Range of nitrate concentration of different vegetable species on Helsinki market summer and autumn 1984.

\begin{tabular}{lccc}
\hline \multirow{2}{*}{$\begin{array}{l}\text { Species } \\
\text { sumples }\end{array}$} & $\begin{array}{c}\text { Number of } \\
\text { samples }\end{array}$ & mean & range \\
\hline $\begin{array}{l}\text { Butter head } \\
\text { lettuce }\end{array}$ & 55 & 1835 & $175-3898$ \\
$\begin{array}{l}\text { Chinese } \\
\text { cabbage }\end{array}$ & 60 & 1057 & $173-2126$ \\
$\begin{array}{l}\text { Kohlrabi } \\
\text { Turnip }\end{array}$ & 21 & 1008 & $195-1737$ \\
$\begin{array}{l}\text { Crisphead } \\
\text { lettuce }\end{array}$ & 32 & 908 & $124-2658$ \\
Cabbage & 40 & 964 & $85-3544$ \\
Carrot & 89 & 607 & $64-1949$ \\
\hline
\end{tabular}

(table 2). The mean concentration of cabbage samples taken in the summer was almost twice as high as that of the samples taken in the autumn. The mean value for carrot samples in the summer was roughly $40 \%$ higher than for those taken in the autumn.

In two species there was a trend clearly opposite to the other species. In the autumn crisphead lettuce samples had a mean nitrate concentration $62 \%$ higher than in the summer. The difference was even more clear in butter head lettuce: the autumn samples' concentration of nitrates was about 2.3-fold compared with that of the summer samples.

Table 2. $\mathrm{NO}_{3}$-concentration $\mathrm{mg} \mathrm{NO}_{3} / \mathrm{kg} \mathrm{FW}$ of each vegetable species in summer (18. 6.-17. 8. 84) and autumn (26. 9.-28. 11. 84) samples.

\begin{tabular}{lrrrrrrr}
\hline Species & \multicolumn{3}{c}{ Summer samples } & & \multicolumn{3}{c}{ Autumn samples } \\
\cline { 2 - 4 } \cline { 5 - 7 } & $\mathrm{n}$ & mean & range & & $\mathrm{n}$ & mean & range \\
\hline Butter head lettuce & 24 & 1050 & $175-2126$ & & 31 & 2443 & $284-3367$ \\
Chinese cabbage & 12 & 964 & $230-1488$ & & 48 & 1081 & $266-2126$ \\
Kohlrabi & 16 & 923 & $195-1737$ & & 5 & 734 & $390-1063$ \\
Turnip & 14 & 1094 & $137-2304$ & & 18 & 762 & $124-2658$ \\
Crisphead lettuce & 17 & 662 & $85-2481$ & & 23 & 1070 & $443-3544$ \\
Cabbage & 32 & 812 & $120-1772$ & & 57 & 412 & $64-1949$ \\
Carrot & 33 & 326 & $53-744$ & & 63 & 231 & $39-567$ \\
\hline
\end{tabular}

Table 3. The distribution $(\%)$ in various $\mathrm{NO}_{3}$-concentration classes of cabbage, chinese cabbage and carrot. $\mathrm{O}=$ organically, $\mathrm{C}=$ conventionally grown. Samples taken $26.9 .-28.11 .84$.

\begin{tabular}{ccccccccc}
\hline \multicolumn{8}{c}{ Cabbage mg NO$/ \mathrm{kg} \mathrm{FW}$} \\
\hline & $\overline{\mathrm{x}}$ & $\mathrm{n}$ & $<250$ & $250-500$ & $500-750$ & $750-1000$ & $1000-1250$ & $>1250$ \\
\hline $\mathrm{O}$ & 394 & 17 & 53 & 29 & 12 & 0 & 0 & 6 \\
$\mathrm{C}$ & 422 & 40 & 25 & 51 & 18 & 2 & 2 & 2 \\
\hline
\end{tabular}

\begin{tabular}{|c|c|c|c|c|c|c|c|}
\hline \multicolumn{8}{|c|}{ Chinese cabbage $\mathrm{mg} \mathrm{NO}_{3} / \mathrm{kg} \mathrm{FW}$} \\
\hline & $\overline{\mathrm{x}}$ & $\mathrm{n}$ & $<500$ & $500-1000$ & $1000-1500$ & $1500-2000$ & $>2000$ \\
\hline $\mathrm{O}$ & 892 & 12 & 25 & 42 & 8 & 17 & 8 \\
\hline $\mathrm{O}$ & 1115 & 36 & 8 & 36 & 39 & 11 & 6 \\
\hline
\end{tabular}

\begin{tabular}{ccccccccc}
\hline \multicolumn{8}{c}{ Carrot $\mathrm{mg} \mathrm{NO}_{3} / \mathrm{kg} \mathrm{FW}$} \\
\hline & $\overline{\mathrm{x}}$ & $\mathrm{n}$ & $<100$ & $100-200$ & $200-300$ & $300-400$ & $400-500$ & $>500$ \\
\hline $\mathrm{O}$ & 127 & 15 & 13 & 60 & 20 & 7 & 0 & 0 \\
$\mathrm{C}$ & 206 & 48 & 17 & 46 & 17 & 10 & 8 & 2 \\
\hline
\end{tabular}


Nitrate concentration of organic and conventional samples

As the number of organically grown samples in the summer was small, one to six, compared to that of conventionally grown, only the autumn samples of three species are given attention to (table 3). Half of the organic cabbage samples in the autumn had nitrates less than $250 \mathrm{mg} / \mathrm{kg} \mathrm{FW}$, while half of the conventional samples belonged to the concentration class $250-500$. In both groups $94 \%$ of samples had nitrates less than 750 $\mathrm{mg} / \mathrm{kg} \mathrm{FW}$.

A fourth of organic chinese cabbage samples had nitrates less than $500 \mathrm{mg} / \mathrm{kg} \mathrm{FW}$, and of conventional samples $8 \%$. On the other hand, a fourth of organic samples had nitrates over $1500 \mathrm{mg} / \mathrm{kg} \mathrm{FW}$, while the corresponding percentage for conventional samples is 17 . About two thirds of both organic and conventional carrot samples had nitrates less than $200 \mathrm{mg} / \mathrm{kg} \mathrm{FW}$.

\section{The development of nitrate concentrations throughout the sampling period}

In cabbage and carrot a diminishing trend is found in nitrate concentrations towards autumn (figure 1). However, the last two monthly means of nitrate concentration in

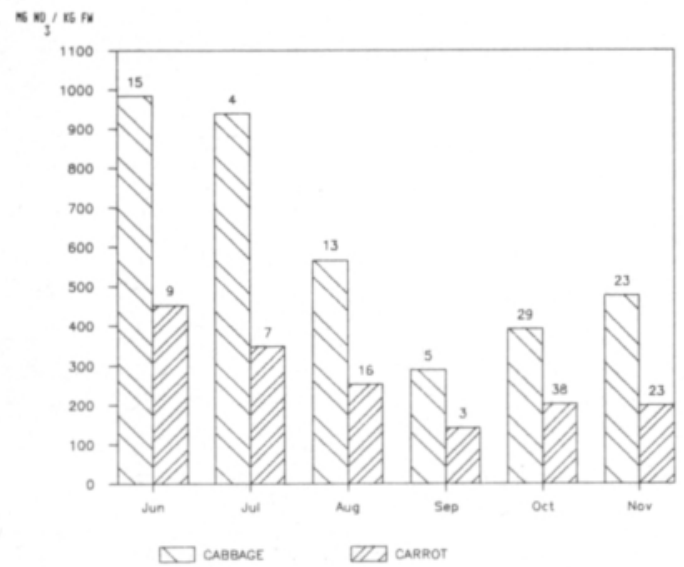

Fig. 1. Monthly nitrate concentration means and number of cabbage and carrot samples. cabbage are higher than that from the previous month. The nitrate concentration of carrot samples was usually about a half of that of cabbage.

From butter head lettuce least nitrates were found in samples taken in June ( $\bar{x} 885 \mathrm{mg}$ / $\mathrm{kg}$ FW) and highest concentrations in November ( $\bar{x} 2685 \mathrm{mg} / \mathrm{kg} \mathrm{FW}$ ) (figure 2). The corresponding nitrate concentrations for crisphead lettuce are $447 \mathrm{mg} / \mathrm{kg} \mathrm{FW}$ in August and 1976 mg/kg FW in November. From August to October the mean concentrations for butter head lettuce nitrates were more than twice as high as those of crisphead lettuce.

\section{Discussion}

Corre and Breimer (1979) grouped vegetable species according to the so called natural limits for their maximum nitrate concentrations. According to them these limits, as $\mathrm{mg}$ $\mathrm{NO}_{3} / \mathrm{kg} \mathrm{FW}$, are the following: lettuce and chinese cabbage over 2500, kohlrabi 10002500 , carrot and cabbage 500-1000. In certain unfavourable conditions these concentrations can, however, rise even threefold (ANON 1984). The maximum concentrations detected in our investigation fitted quite well in these frames. Only cabbage had a maximum value, 1772, higher than the natural limits for it.

Different types and cultivars within one

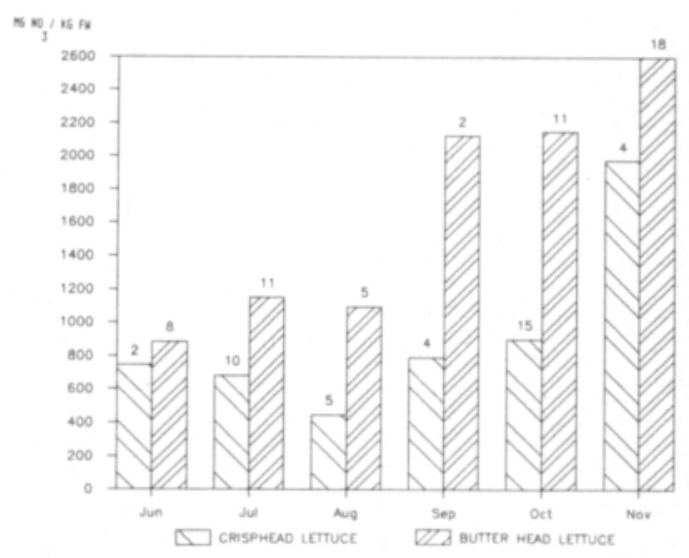

Fig. 2. Monthly nitrate concentration means and number of butter head and crisphead lettuce samples. 
vegetable species are known to contain nitrates in different amounts. For example crisphead lettuce has earlier been found to contain more nitrates than butter head types (MAYNARD et al. 1976). In agreement with the results of LöNBERG et al. 1985, in our investigation crisphead lettuce contained nitrates less than butter head lettuce did, specially in the autumn months. Light has an effect on nitrate accumulation in a plant, as it influences the activity of its nitrate reducing enzymes (CORRE \& Breimer 1979). The autumn months of the year 1984 were exceptionally cloudy. This might to some extent explain the high nitrate concentration of lettuce and crisphead lettuce harvested in November. Moreover, samples late in the autumn were mostly taken from greenhouse grown products. Lettuce grown in greenhouse has been found to contain greater amounts of nitrates than field grown (von SEITZ 1984).

The nitrate concentration means of organically grown products were usually lower than those of conventionally grown. However, also among these samples there were some with high nitrate concentration.

Nitrate concentration means received in this study were equal to or lower than those from earlier studies in Finland. The mean nitrate concentrations mg/kg FW from earlier Finnish studies (ANON 1983) and those in our study, correspondingly, are the following: chinese cabbage 3475/1057, kohlrabi 2210/ 1008 , carrot $279 / 264$ and butter head lettuce $2124 / 1835$. Only cabbage had a mean value, 607 , a little higher than that of earlier studies, 561.

\section{References}

ANON 1983. NONO-työryhmän mietintő. Nitraatti, nitriitti ja $\mathrm{N}$-nitrosoyhdisteet elintarvikkeissa. Elinkeinohallitus. 66 p. Helsinki.

ANON 1984. Nitrat-Kongress in Karlsruhe. Deutscher Gartenbau 39: 1726.
The Swedish study mentioned above (LöNBERG et al. 1985) deals with an annual development of nitrate concentration in some vegetable species on market. It gives a nitrate concentration mean for cabbage $(620 \mathrm{mg} / \mathrm{kg}$ FW) and chinese cabbage (1100 mg/kg FW) very similar to those of our investigation (607 and $1057 \mathrm{mg} / \mathrm{kg} \mathrm{FW}$, correspondingly). The Swedish study gives a nitrate concentration mean for carrot, $1100 \mathrm{mg}$, fourhold to ours, and that of butter head lettuce, $2900 \mathrm{mg} / \mathrm{kg}$ FW, about $60 \%$ higher than the Finnish mean concentrations. However, in our study the sampling period didn't exceed in winter months with poorest light conditions, which might have an effect on the butter head lettuce concentrations of nitrates.

During the past few years some European countries have set the highest acceptable nitrate concentration for lettuce on the market. The upper limits, depending on the country, are between 3500 to $5000 \mathrm{mg}$ nitrates/ $\mathrm{kg} \mathrm{FW}$. Only two samples in our study had concentrations higher than $3500 \mathrm{mg} / \mathrm{kg}$.

\section{Conclusions}

Time of year seems to have an influence on the nitrate concentration of some vegetable species. When growing lettuce in poor light conditions, much attention should be paid to cultural practices, specially nitrogen fertilizing.

Domestic fresh market vegetables in summer and autumn can be regarded safe as regards their nitrate concentration.

Corre, W.J. \& Breimer, T. 1979. Nitrate and nitrite in vegetables. 85 p. Wageningen.

Lonberg, E., Everitt, G. \& Mattsson, P. 1985. Nitrat i grönsaker. Vår föda 37: 316-322.

Maynard, D.N., Barker, A.V., Minotti, P.L. \& Peck, 
N.H. 1976. Nitrate accumulation in vegetables. Adv. in Agron. 28: 71-118.

Mä́äräınen, E. 1984. Suomalaisen ruokaperunan nitraattipitoisuus. Elinkeinohallitus. Kuluttaja-asiain osaston julkaisuja. Sarja A 6/84. 84 p. Helsinki.

\section{SELOSTUS}

\section{Kotimaisten vihannesten nitraattipitoisuus Helsingin markkinoilla kesällä ja syksyllä 1984}

\section{Seija Ahonen ja Iris Kuokkanen}

Helsingin yliopisto

Puutarhatieteen laitos

SF-00710 Helsinki

\section{Pirjo-Liisa Penttilä}

\section{Elinkeinohallitus}

Kuluttaja-asiainosasto

PL 9, SF-00531 Helsinki

Eräiden Helsingin seudulla kaupan olevien kotimaisten vihannesten nitraattipitoisuutta seurattiin Elinkeinohallituksen toimesta kesällä ja syksyllä 1984. Vihanneslajit olivat keräkaali (Brassica oleracea var. capitata), salaattikiinankaali (Brassica pekinensis), kyssăkaali (Brassica oleracea var. gongylodes), nauris (Brassica rapa), porkkana (Daucus carota subsp. carota) sekä pehmeă ja rapea keräsalaatti (Lactuca sativa var. capitata). Näytteită oli 395, joista viidesosa oli ilmoitettu luonnonmukaisesti viljellyiksi. Näytteiden nitraattipitoisuus määritettiin ionispesifisellä elektrodilla Helsingin yliopiston puutar-
Sertz, P. von 1984. Ergebnisse von Nitratuntersuchungen. Gemüse 12: $420-421$.

Ms received October 15, 1987 hatieteen laitoksella.

Kunkin vihanneslajin nitraattipitoisuus vaihteli suuresti. Näytteiden nitraattipitoisuuden keskiarvot milligrammoina nitraatteja tuorepainokiloa kohti olivat seuraavat: pehmeă keräsalaatti 1835, kiinankaali 1057, kyssăkaali 1008, rapea kerăsalaatti 964 , nauris 908 , kerăkaali 607 ja porkkana 264. Syksyn pehmeän keräsalaatin năytteiden nitraattipitoisuus oli yli kaksinkertainen verrattuna kesăn näytteisiin, keräkaalilla päin vastoin. Kesăllă porkkananäytteiden nitraattipitoisuuden keskiarvo oli noin $40 \%$ suurempi kuin syksyllä. 